Because these theoretical, mechanical, electron microscopic and electrical properties are like those attributed to the cell membrane and because this experimental membrane is made from solubilized lipids extracted from membrane structures of white matter, we suggest that it is reconstituted cell membrane structure. Evidently it can exist in stable form in the absence of all other cell components and, in addition, can show the cellular function of electrical excitability, and perhaps other cell functions as well, when the composition of the lipid phase and the nature of the adsorbed molocules are properly solocted.

$$
\begin{aligned}
& \text { Paul Mueller } \\
& \text { Donali O. Rudin } \\
& \text { H. Ti Tien } \\
& \text { William C. Wesoot }
\end{aligned}
$$

Department of Basic Research,

Eastern Pennsylvania Psychiatric Institute, Philadelphia 29, Penn.

'Folch, J., and Lees, M., J. Biol. Chem., 191, 807 (1051).

"Hooke, R., Loy. Soc. Meetiug, 1672, in The History of the Roy.

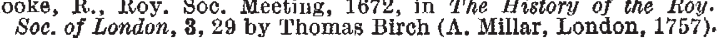
${ }^{3}$ Newton, I., Opticks (1704), 214 and.233_(reprinted by Dover, New York, 1952)

- Perrin, J., Ann. Phys., 10, 160 (1918).

Blinks, L. R., J. Gen. Physiol., 19, 633 (1936).

- Finkelstein, A., Nature, 190, 1119 (1961).

${ }^{7}$ Mueller, P., J. Gen. Physiol., 42, 137 (1958).

\section{Some Extremely High Acuities of Taste for Phenylthiocarbamide}

Is human population groups a primary dichotomy (so-called 'non-taster' and 'taster' classes with some overlap) in the distribution of thresholds of taste for phenylthiocarbamide (PTC) was established by the early work of Hartmann ${ }^{1}$ and othors. Falconer ${ }^{2}$ noted the irregular nature of the distributions of 'non-taster' material; and Lugg and Whyt $\Theta^{3}$, from the results (corrected for the effocts of ago and sex) of their investigations of southern Chinese, European, southern Indian and Malay ethnic groups, considered these distributions to be potentially (if not always actually) bimodal, a view which was supported by subsoquont work ${ }^{4}$ on Negrito and Senoi subjects. They ${ }^{3}$ also questioned the presumption that 'taster' material is always unimodally distributed; but it was realized ${ }^{4}$ that the distribution irregularities might be due to sampling errors rather than to intrinsic causes. The question remained open, however, and it was hoped that clarification of the overall picture of threshold distributions might come with the accumulation of additional data from work on other ethnic groups.

Results of work recently done in Hokkaido on Japanese and Ainu ethnic groups and on persons of mixed origin support the view that 'taster' material is, potentially, not unimodally distributed. Thero is appreciable evidence that, apart from the earlier suggested category of 'high acuity tasters', a category of 'extremely high acuity tasters' exists in these, if not other, groups.

The PTC solutions used in these investigations comprise a series integrally numbered from zero, the concentration of solution numbored $n$ being $2 \cdot 60$ $\times 2^{-n} \mathrm{gm}$. PTC/1. A subject demonstrates his ability to discriminate between solution $n$ and solvent (distilled water) in a sorting trial, the chance of success by guosswork being $0 \cdot 125$, and his most likely threshold value ${ }^{3}$ is $n+0 \cdot 5$. The taste-quality he reports is not necessarily the characteristic quality, bitter, experienced with more concentrated solutions.
It was among the Kintak Bong Negritos of Malaya that the tasters of proviously highest acuity were encountered $^{5}$, one subject succeeding with solution 18. His reaction in the trial was such as to suggest that he may have succeeded with at least solution 19 if it had been possible then to test him further. In the Hokkaido work it has been found necessary to extend the range to solution 24 in order to carry out the survey offectively. Of fifty 'pure' or almost 'pure' Ainu and of fifty Japanese subjects, seven in each sample succeeded with solution 18 or higher number; and of an extremoly heterogeneous sample of fifty persons of mixed extraction containing many children in the 10-14-year age-range, a factor predisposing to more successes with solutions of higher number, twolve successes were recorded. In all, three subjects succeeded with solution 19 , eight with 20 , four with 21 , three with 22 (one of them describing the taste as bitter and the other two as astringent), and one, a 14-year-old Ainu boy who described the taste as sweet, with 23.

Solutions 18 and 23 contain 9.9 and $0.31 \mu \mathrm{gm}$. PTC/1. and are $6.6 \times 10^{-8}$ and $2.1 \times 10^{-9}$ molar, respectively. The subject takes $2.5 \mathrm{ml}$. of solution (or solvent) into tho mouth in each step of a sorting trial, representing $2.5 \times 10^{-8} \mathrm{gm}$. or $1.6 \times 10^{-10} \mathrm{~mole}$ or some $10^{14}$ molecules of PTC with solution 18 , and $8 \times 10^{-10} \mathrm{gm}$. or $5 \times 10^{-12}$ mole or $3 \times 10^{12}$ molecules with solution 23. If Moncrieff' $s^{6}$ estimate is accepted, namely, that $0.05 \mathrm{ml}$. of solution, properly applied, is sufficient for taste-testing, the number of molecules of PTC involved would be $2 \times 10^{12}$ with solution 18 (not $8 \times 10^{9}$ stated earlier ${ }^{5}$ as the result of a miscalculation) and $6 \times 10^{10}$ with solution 23 .

The Nogrito subject's success with solution 18 ranked him as the most acute taster of any substance among human subjects examinod up to that time ${ }^{5}$. Yet, of tho 150 persons examined recently in Hokkaido some 17 per cent rank either in his company or (the 14-year-old Ainu boy in excelsis) considorably above him. Tasting acuities of this higher order lie far beyond any previously recorded and were utterly unexpected when the work was begun.

Proper acknowledgement of help received will be made elsewhere, when the full account of this work and discussion of its implications in anthropologica] studies are published. Mention can here be made only of the many forms of assistance rendered by Prof. S. Watanabe, but for whose prior interest the Hokkaido programme could not have been undertaken.

Department of Anatomy,

Sapporo Medical College, Sapporo, Japan.

* Guest worker, on leave from the University of Western Australia. ${ }^{2}$ Hartmann, G., Ann. Eugen., 9, 123 (1939).

2 Falconer, D. S., Ann. Eugen., 13, 211 (1940).

sugg, J. W. H., and Whyte, J. M., Ann. Human Genet., 19, 290 (1955).

sugg, J. W. H., Ann. Human Genet., 21, 244 (1957).

sugg, J. W. H., Nature, 176, 313 (1955).

- Moncrieff, R. W., The Chemical Senses (Leonard Hill, Ltd., London, 1944).

\section{Hæmophilia and the Protease Inhibitor in Peanuts}

Boudreaux and Frampton's report ${ }^{1}$ on a hæmostatic factor in peanuts (Arachis hypogaea), orally active in hrmophilic patients, aroused great interest. Since these and other investigators have boen unable to 